\title{
Who benefits of trade with China? \\ Examining the effects of free trade \\ agreements on trade flow with China \\ using an adjusted gravity model
}

\author{
Sigurður Guðjonsson \\ School of Business, University of Iceland, \\ Iceland \\ siggig@,hi.is \\ ORCID 0000-0001-8897-3699
}

Inga Minelgaite

School of Business, University of Iceland,

Iceland

inm@,bi.is

ORCID 0000-0002-4026-3222

Hrafnhildur Kristinsdóttir

Marketing Consultant

brafnbildurkristins@gmail.com

Jelena Stankevičienè

Department of Financial Engineering,

Vilnius Gediminas Technical University,

Lithuania

jelena.stankeviciene@vilniustech.lt

ORCID 0000-0002-5600-5842

Abstract. China has numerous free trade agreements with various countries. In this research it will be examined who benefits from those free trade agreements. The sample includes 27 countries trading with China but 13 of these countries have signed a free trade agreement with China, or roughly half of all the available countries in our sample. The sample data are from 2001 - 2017. An adjusted gravity model and a linear regression was carried out. While those countries that have made free trade agreement with China experienced modest or no increase in export to China, China itself experienced significant increase in export to its 
export to these countries as well. It is therefore safe to conclude that China is a beneficiary of free trade agreements at least as much as it's trade partners.

Keywords: China, free trade agreements, gravity model, import, export, international business

JEL Classification: C3, F14

\section{INTRODUCTION}

With the emergence of free trade agreements between countries, questions are raised regarding whether these agreements increase trade between the participating countries or bring them any benefits and moreover who benefits. Free trade agreements eliminate restrictions on imports and exports between countries. Many countries participate in trade, and throughout history, nations have benefitted by taking part in international trade (Bergstrand, 1985; Markusen, 2004; Nguyen, 2019; Do et al., 2020). Various studies have demonstrated that trade flow follows the heuristic model of the gravity theory (Linnemann, 1966; Tinbergen, 1962). The quantification of bilateral trade consists of prosperous economic growth and overcoming income and trade barriers, the latter of which generally consists of distance, transport costs, trade agreements and cultural differences (e. g. Baier \& Bergstrand, 2007; Bunt \& Klaasen, 2007; Grant \& Lambert, 2008; Beugelsdijk, Ambos \& Nell, 2018; Shahriar, Qian \& Kea, 2019).

This research aims to examine who benefits of free trade agreements with China. Historical data from IMF is used. The time period of the sample data analysis are from $2001-2017$. China's imports and exports have been increasing greatly over the last years, of more than 600\% from 2001 to 2011 and continues to grow (WTO, 2015). China became the second largest economy in the world in 2012 and by 2016 its foreign trade accounted for about 13\% of the world trade (Zhao \& Ruet, 2020).

As with many researches that look at historical trade flow between countries, the gravity model will be used, the gravity model has been used to shed light on the effects of trade on a national level. As highlighted by Baier and Bergstrand (2007), the gravity model has been used over the years to analyse international trade and, more specifically, the impact of free trade agreements on trade flow. This approach connects bilateral trade flows to many factors that influence trade barriers, including distance and gross domestic product (GDP) (Anderson \& van Wincoop, 2003).

The literature shows mixed results. For example, Rose (2004), Endoh (2010) as well as Linse and Mugge (2019) showed that free trade between countries has a relatively minor effect on the volume of trade, while other studies exploring free trade agreements have demonstrated that they do indeed produce more trade between countries (Bagwell \& Staiger, 2005; Eicher \& Henn, 2011; Handley, 2012; Subramanian \& Wei, 2007; Lakatos \& Nilsson, 2017; Xiang, Kuang \& Li, 2017; Kang \& Yoon, 2020).

Research concerning gravity-like theories about trade flow between countries usually takes into account macroeconomic variables. In the empirical literature, the variables used are GDP, GDP per capita (GDPPC), and distance as these variables highly predict possible trade (Bayoumi \& Eichengreen, 1997; Frankel \& Rose, 2002; Sarker \& Jayasinghe, 2007; Beugelsdijk et al., 2019).

This research will expand the existing literature by implementing an adjusted gravity-model equation with regards to globalization. With the adjusted gravity model, it will be possible to see changes in trade between China and their free trading partners. Furthermore, in comparison, we examined countries trading with China, some of which did not have free trade agreement with China and others that did.

Scholars in the field of international trade have added the variable of the Konjunkturforschungsstelle (KOF) Globalization Index (KOFGI) from the KOF Swiss Economic Institute to the gravity model (Gygli 
et al., 2019). This approach has shown that growth in trade flow and economic expansion do follow globalization patterns significantly (Dreher, 2006). The index assesses the political, economic, and social aspects of globalization, and it is used to observe any adjustments in the stage of globalization of different countries over a period of time (Eidgenössische Technische Hochschule Zurich, 2020). The index has data for 195 nations spanning nearly 50 years.

This research first discusses the existing literature and theoretical background and the hypotheses, then presents the gravity model, variables and data. Regression analysis is conducted and the results are discussed, and finally, a conclusion is presented.

\section{THEORETICAL BACKGROUND}

The gravity model has come to be used more and more frequently since it was first introduced. Anderson (1979), McCallum (1995), and Anderson and van Wincoop (2003) have enriched the theoretical background, which was barely present at first, and furthermore, they have improved the model with their research. Even though the literature surrounding the gravity model and its usage is rich, the results regarding the effect that FTAs have on trade varies.

Over the years, China has entered into FTAs with Australia, Chile, Costa Rica, Georgia, Iceland, the Maldives, Mauritius, New Zealand, Pakistan, Peru, Singapore, the Republic of Korea, and Switzerland (China FTA Network, n.d.).

China entered the WTO in 2001 after a lengthy and cautious negotiation process (Subramanian \& Wei, 2007). However, upon entering the WTO, China did not immediately enter into FTAs with Western countries; instead, it first established FTAs with other countries within Asia (Kien \& Hashimoto, 2005). In 2003, soon after China's entry into the WTO and its FTAs with other Asian countries, the ASEAN-China Free Trade Area agreements (ACFTA) was founded. This pushed other AFTA member states to reassess their free trade arrangements based on the conditions of the ACFTA agreements (Baldwin, 2006).

Upon joining the WTO in 2001, China experienced a boost in both imports and exports (World Bank, 2019). According to the WTO (2015), the overall value of China's imports and exports grew by over $600 \%$ in the first ten years after China joined the WTO. Although China did experience a decrease in international trade alongside other countries during the recession in 2008 and 2009 (Lai \& Li, 2013), this sector did increase again and has been growing ever since (WTO, 2015). China has gained considerable benefits from joining the WTO. More specifically, it has seen an increase in import and export business with the USA (Handley \& Limao, 2013; Melchior, 2018) and significant development of its free trade with other prominent trading participants around the world, including both European and other Asian nations (WTO, 2015). It is very important to China to have a significant and lasting partnership with the EU (Brugier, 2017; Chang \& Pieke, 2017; Griese, 2006). However, even though China's trading has increased, it exercises caution when entering into more FTAs with other countries, especially with first-world economies such as EU member states.

The careful consideration that China undertakes in choosing countries to trade with within Europe comes from distrust toward the EU; as result of this, China has focused more on European countries outside the EU such as Iceland and Norway (Lanteigne, 2010; Medin, 2019). By taking this careful approach, China can create a test market area and perhaps enter the EU market "through the back door" since some countries that have FTAs with China are members of the EU through the EEA (Lanteigne, 2010).

The whole dataset is examined with regard to the effects of an FTA; i.e., all countries already engaged in an FTA with China. This will provide a reasonable estimate of the effects of an FTA with China.

Zhang et al. (2007) noted that the FTAs entered into by China up until 2007 had a significant positive effect on trade flow. Following these results and the assumptions the current paper intends to make, it is 
hypothesized that analyzing the factors explaining trade flow shall reveal that both exports and imports to China will increase in general after a country enters into an FTA with China. On this basis, and in line with the literature (Bagwell \& Staiger, 2005; Baier \& Bergstrand, 2007; Eicher \& Henn, 2011; He, Lin \& Liu, 2020; Zhao \& Ruet, 2020), the following hypotheses are formulated:

Hypothesis One: Countries that have entered into an FTA with China experience an increase in exports to China.

Hypothesis Two: Countries that have entered into an FTA with China experience an increase in imports from China.

\section{METHODOLOGY}

\subsection{Model Setup and Variables}

As discussed above, the gravity model has been widely used to explore the dependent variables concerning trade flows between entities with relation to macroeconomic independent variables. Various independent variables are used in the model: country size, income, exchange rate, and difference in price between countries. The model presents a positive correlation in bilateral trade in terms of the size of the regions macroeconomically as follows:

$$
T_{i j}=A\left(Y_{i} Y_{j}\right) /\left(D_{i j}\right),
$$

where $T i j$ is the bilateral trade flow (total import and export between countries $i$ and $j$ ), $Y i$ and $Y j$ stand for the GDP values of $i$ and $j, D i j$ is the distance between the countries, and $A$ is a constant.

In his research, Tinbergen (1962) implemented Newton's law in relation to international trade as follows:

$$
F_{i j}=G M_{i}^{\alpha} M_{j} \beta / D_{i j} \theta,
$$

where $F_{i j}$ is the trade flow between countries $i$ and $j, M_{i}$ and $M_{j}$ are the economic sizes of countries $i$ and $j$, respectively, $D_{i j}$ is the distance between countries $i$ and $j$, and $G$ is a constant. To avoid extensive variation in the size of the economies of $i$ and $j$ and the distance between them, a natural logarithm can be used:

$$
\ln \left(T_{i j}\right)=a_{0}+a_{1} \ln \left(Y_{i} * Y_{j}\right)+a_{2} \ln \left(D_{i j}\right) .
$$

Research on FTAs using the adjusted gravity model has usually found positive results; that is, that FTAs do have a positive impact in increasing overall trade flow between countries (Péridy, 2005; Shujiro \& Misa, 2007; Yihong \& Weiwei, 2006; He, Lin \& Liu, 2020; Zhao \& Ruet, 2020). In these studies, a dummy binary variable is often used, which takes the value 0 or 1 depending on whether an FTA is in effect or not (Aitken, 1973; Bergstrand, 1985, 1989; Linneman, 1996). It is known that the FTA dummy variable could be connected to unknown variables that do correlate with trade flow (Baier \& Bergstrand, 2002), and therefore, the effect of the FTA on the gravity model (when applicable) could be overrated. Looking back to data from the middle of the $20^{\text {th }}$ century concerning trade flows, a clear direction in the increase in trade can be observed, possibly due to shorter transport times and improving lines of communication (Kim \& Shin, 2002). As stated above, the KOFGI is used in the current study, as it has been shown that growth in trade flow and economic expansion do follow globalization patterns to a significant extent (Dreher, 2006; Gygli et al., 2019). By including globalization in the model, the importance of FTAs is reduced; consequently, the model is more specific and practical.

This research uses an adjusted version of the gravity model. The variables of GDP and distance will still be used, but those of GDPPC, FTA, KOFGI, and IncomeGAP will be added. A natural logarithm will be 
applied to the numerical variables GDP, GDPPC, D, IncomeGAP and KOFGI to even out variation between countries. The variable FTA is categorical and will be left untouched. The adjusted model is as follows:

$$
\begin{aligned}
\ln \left(\text { Trade }_{i j}\right)= & a_{0}+a_{1} \ln \left(G D P_{i j}\right)+a_{2} \ln \left(G D P P C_{i j}\right)+a_{3} \ln \left(D_{i j}\right)+a_{4} \ln \left(\text { IncomeGAP }_{i j}\right) \\
& +a_{5} \ln \left(\text { KOFGI }_{i}\right)+a_{6} F T A_{i j}
\end{aligned}
$$

Table 1

\begin{tabular}{|c|c|}
\hline Explanatory variables & Meaning \\
\hline Trade $_{i j}$ & $\begin{array}{l}\text { The total volume of import and export trade between } \\
\text { country } i \text { and China (j) in US dollars (US\$). }\end{array}$ \\
\hline$G D P_{i j}$ & The GDP of country i times the GDP of China (j). \\
\hline$G D P P C_{i j}$ & $\begin{array}{l}\text { The GDPPC of country i times the GDPPC of country } \\
\text { China (j). }\end{array}$ \\
\hline$D_{i j}$ & The distance between country $i$ and China $(j)$. \\
\hline IncomeGAP $P_{i j}$ & $\begin{array}{l}\text { The absolute value of the difference in GDPPC } \\
\text { between country } i \text { and China (j) }\end{array}$ \\
\hline KOFGI & The KOFGI of country i compared to China. \\
\hline$F T A_{i j}$ & $\begin{array}{l}\text { A binary variable indicating whether there exists an } \\
\text { FTA between country } i \text { and China (j). }\end{array}$ \\
\hline
\end{tabular}

Meaning of variables used in the adjusted gravity model

Source: Authors' own study

$M_{i j}$ stands for the total volume of import and export trade between country $i$ and China (j), seen from country $i$. As the model is intended to predict the effects of the FTA on trade for country $i$ with China, it is clear that all numbers should be from the perspective of country $i$. The variable GDP is used to evaluate the market value of all goods and services that are produced or each country, and GDPPC is selected because it is commonly considered to stand for the individual growth of each economy. $D_{i j}$ represents the distance from the capital of country $i$ to the capital of China $(j)$. IncomeGAP $i j$ is evaluated by taking the absolute difference between GDPPC for each country to assess the effect of the difference is between the countries' average income levels (Shujiro \& Misa, 2007). FTA ij $_{i j}$ a dummy variable that stands for the general effect of an FTA on trade between countries; it is based on data concerning trade between nine countries of which have an FTA with China. Assuming that the overall impact of FTAs is positive (Shujiro \& Misa, 2007), the coefficient of the variable should be positive; in other words, it is expected to reflect that FTA does increase trade flow. GDP and GDPPC stand for the economic size and income of individual countries; therefore, it is expected that these variables should have a positive impact on overall trade. Regarding differences in income (IncomeGAP), this could have either a negative or positive effect on trade flow for different countries; a significant difference could have a positive impact on trade between industries, while insignificant differences could increase trade within a particular industry (Glesjer et al., 1982). In the adjusted model, there is no variable that stands directly for transport costs. Instead, these costs are evaluated with regard to distance; that is, it is assumed that an increase in the distance to be covered would result in an increase in export costs.

\subsection{Data}

The sample that this research utilizes is derived from data gathered from 13 independent countries that conduct trade with China.

The data for trade value of imports and exports is in US\$ million at the current exchange rate, and it was gathered in 2020 from the International Monetary Fund's (IMF) reports regarding trade flow between countries (IMF, 2020). The IMF does not acknowledge Palestine as an independent country; consequently, 
Palestine is not taken into account for this sampling. The GDP and GDPPC data are sourced from The World Bank Group (2019). GDP stands for the amount of the total gross value combined with total citizen producers in the economy, in addition to any product taxes but without any subsidies that are excluded from the product's value. This figure is determined without subtracting depreciation of manufactured property (World Bank, 2019). The data are presented in US\$. The dollar amount for GDP is modified from domestic currencies using a single-year official exchange rate. For some countries, an alternative conversion factor is used as the official exchange rate does not indicate the rate effectively used for physical foreign exchange transactions.

The variable $D_{i j}$ is defined as the distance of a direct airline between the capital of country $i$ and the capital of China ( $)$, and it is a constant for each country independently. All missing values are removed from the dataset. The main issue is the correlation of trade flow with growing globalization (Davis \& van Wincoop, 2018), but to minimize this effect, the KOFGI has been included as a predictor (Gygli et al., 2019). However, it is noted that a positive relationship between globalization and the economic growth of particular countries is strongly supported (Dreher, 2006; Potrafke, 2014).

There are total of thirteen countries in the sample that have FTAs with China: Australia, Chile, Costa Rica, Georgia, Maldives, Mauritius, Iceland, New Zealand, Pakistan, Peru, Singapore, the Republic of Korea, and Switzerland. Each of these countries has had an FTA in place with China for several years.

Table 2 shows the descriptive statistics for the FTA-specific countries.

Table 2

Descriptive statistics for FTA-specific countries

\begin{tabular}{|c|c|c|c|c|c|}
\hline & $\mathbf{N}$ & Minimum & Maximum & Mean & Std. Deviation \\
\hline $\ln \left(\right.$ Trade $\left._{i j}\right)$ & 153 & 4.29 & 2.38 & 8.8959 & 1.95893 \\
\hline $\ln \left(\right.$ Export $\left._{i j}\right)$ & 153 & 2.19 & 11.89 & 7.8647 & 2.41079 \\
\hline $\ln \left(\right.$ Import $\left._{i j}\right)$ & 153 & 4.16 & 11.48 & 8.3047 & 1.77830 \\
\hline $\ln \left(\right.$ GDP $\left._{i j}\right)$ & 153 & 50.75 & 58.18 & 54.8247 & 1.67017 \\
\hline $\ln \left(G D P P C_{i j}\right)$ & 153 & 13.16 & 20.37 & 17.7031 & 1.69271 \\
\hline $\ln \left(D_{i j}\right)$ & 153 & 6.86 & 9.86 & 8.8759 & 0.88122 \\
\hline IncomeGAP $_{i j}$ & 153 & 5.36 & 11.32 & 9.2638 & 1.50723 \\
\hline $\ln \left(\right.$ KOFGI $\left._{i}\right)$ & 153 & 3.86 & 4.51 & 4.2877 & 0.14823 \\
\hline FTA & & 1 & 0.46 & 0.500 \\
\hline Valid N (listwise) & 153 & 0 & & & \\
\hline
\end{tabular}

Source: Authors' own calculations

In comparison, we examined countries trading with China, some of which did not have free trade agreement with China and others that did. In addition to the countries mentioned above are; Bangladesh, Cambodia, Canada, Columbia, Fiji, Israel, Japan, Moldova, Mongolia, Nepal, Norway, Panama, Papa New Guinea, and Sri Lanka.

Table 3 shows the descriptive statistics for all countries in the sample that trade with China. 
Descriptive statistics for all the 27 countries

\begin{tabular}{|c|c|c|c|c|c|}
\hline & \multicolumn{1}{|l|}{$\mathbf{N}$} & Minimum & Maximum & Mean & Std. Deviation \\
\hline $\ln \left(\right.$ Trade $\left._{i j}\right)$ & 455 & 0.44 & 12.75 & 7.8313 & 2.46744 \\
\hline $\ln \left(\right.$ Export $\left._{i j}\right)$ & 454 & -4.61 & 11.99 & 5.8960 & 3.59642 \\
\hline $\ln \left(\right.$ Import $\left._{i j}\right)$ & 458 & -0.09 & 12.15 & 7.3856 & 2.40483 \\
\hline $\ln \left(G D P_{i j}\right)$ & 458 & 48.51 & 59.34 & 54.0309 & 2.36781 \\
\hline $\ln \left(G D P P C_{i j}\right)$ & 458 & 12.47 & 20.43 & 17.0128 & 1.91554 \\
\hline $\ln \left(D_{i j}\right)$ & 458 & 6.86 & 9.86 & 8.7318 & 0.73954 \\
\hline IncomeGAP & 45 & 4.07 & 11.47 & 8.6820 & 1.59303 \\
\hline $\ln \left(\right.$ KOFGI $\left._{i}\right)$ & 458 & 3.51 & 4.51 & 4.1711 & 0.22085 \\
\hline$F T A_{i j}$ & 458 & 0 & 1 & 0.15 & 0.360 \\
\hline Valid N (listwise) & 454 & & & & \\
\hline
\end{tabular}

Source: Authors' own calculations

\section{EMPIRICAL RESULTS AND DISCUSSION}

\subsection{Regression results}

The results of the regression analyses will be presented in this chapter. The effects for the countries that have an FTA with China will be examined.

The linear regression equation for export volume between countries $i$ and $j$ at year $t$ is:

$$
\begin{aligned}
\ln \left(\text { Export }_{i j t}\right)= & a_{0}+a_{1} \ln \left(G D P_{i j}\right)+a_{2} \ln \left(G D P P C_{i j}\right)+a_{3} \ln \left(\text { Distance }_{i j}\right) \\
& +a_{4} \ln \left(\text { IncomeGAP }_{i j t}\right)+a_{5} \ln \left(\text { KOFGI }_{i}\right)+a_{6} F T A
\end{aligned}
$$

which defines the export volume between countries $i$ and $j$ per year $t$ as a function of the GDP and GDPPC of each country along with other variables. As formerly stated, the variable FTA is given the value of 1 if an FTA exists between countries $i$ and $j$, or 0 if not. The import volume from country $i$ to country $j$ at year $t$ is calculated as follows:

$$
\begin{aligned}
\ln \left(\text { Import }_{i j t}\right)= & a_{0}+a_{1} \ln \left(G D P_{i j}\right)+a_{2} \ln \left(G D P P C_{i j}\right)+a_{3} \ln \left(\text { Distance }_{i j}\right) \\
& +a_{4} \ln \left(\text { IncomeGAP }_{i j t}\right)+a_{5} \ln \left(\text { KOFGI }_{i}\right)+a_{6} \text { FTA }
\end{aligned}
$$

The data from IMF (2020) does not discriminate between different types of trade, so the sum of all types of trade will be used with when generating the linear regression model.

\begin{tabular}{|c|c|c|c|c|c|c|}
\hline & $\ln \left(G D P P C_{i t}\right)$ & $\ln \left(\right.$ Distance $_{i j}$ & FTA & $\ln \left(G D P_{j t}\right)$ & In $\left(\right.$ IncomeGAP $P_{i j t}$ & $\ln \left(K O F G I_{i}\right)$ \\
\hline $\ln \left(G D P P C_{i j t}\right)$ & 1.000 & & & & & \\
\hline $\ln \left(\right.$ Distance $\left._{i j}\right)$ & -0.124 & 1.000 & & & & \\
\hline$F T A$ & -0.395 & -0.447 & 1.000 & & & \\
\hline $\ln \left(G D P_{i j t}\right)$ & -0.221 & 0.690 & $\begin{array}{c}-0.52 \\
7\end{array}$ & 1.000 & & \\
\hline $\ln \left(\right.$ Income $G A P_{i j t}$ & -0.542 & 0.534 & 0.027 & 0.425 & 1.000 & \\
\hline $\ln \left(K O F G I_{i t}\right)$ & -0.488 & -0.459 & 0.488 & -0.367 & -0.320 & 1.000 \\
\hline
\end{tabular}

In Table 4 , most of the correlation coefficients are above 0.4 , which might indicate some collinearity.

Table 4

Coefficient correlations for the regression model for FTA-specific countries

Source: Authors' own calculations 
For comparison, for the 27 countries (some of which have FTA with China and others that do not) few correlation coefficients were above 0.4 .

Table 5

Coefficient correlations for the regression model for all the 27 countries

\begin{tabular}{|c|c|c|c|c|c|c|}
\hline & FTA & In (Incomed & In (Distanc) & $\ln \left(G D P_{j t}\right)$ & $\ln \left(K_{O O F G I_{i t}}\right.$ & $\ln \left(G D P P C_{i j}\right.$ \\
\hline FTA & 1.000 & & & & & \\
\hline $\ln \left(\right.$ IncomeGAP $\left.P_{i j t}\right)$ & 0.140 & 1.000 & & & & \\
\hline $\ln \left(\right.$ Distance $\left._{i j}\right)$ & -0.136 & 0.269 & 1.000 & & & \\
\hline $\ln \left(G D P_{i j t}\right)$ & -0.208 & -0.141 & 0.239 & 1.000 & & \\
\hline $\ln \left(K O F G I_{i t}\right)$ & 0.022 & -0.280 & -0.277 & -0.123 & 1.000 & \\
\hline $\ln \left(G D P P C_{i j t}\right)$ & -0.124 & -0.404 & -0.167 & -0.330 & -0.460 & 1.000 \\
\hline
\end{tabular}

Source: Authors' own calculations

In determining multicollinearity through variance inflation factor (VIF) testing and tolerance, it is noted that the tolerance never falls under 0.2. As pointed out above, the relationship between globalization and economic growth is a well-known phenomenon that explains the KOFGI-GDPPC relationship (Dreher, 2006; Potrafke, 2014), and the values for GDPPC are also used for IncomeGAP, so this relationship should not be unexpected.

Looking at Table 6, the tolerance and VIF tests are used to determine multicollinearity, and it is noticeable that the tolerance remains above 0.2 except for the variable of GDPPC. That indicates that multicollinearity seems not to be a problem regarding this dataset.

Table 6

Collinearity statistics for the FTA-specific countries

\begin{tabular}{|c|c|c|}
\hline Variable & Tolerance & VIF \\
\hline GDP_LN & 0.331 & 3.022 \\
\hline GDPPC_LN & 0.163 & 6.152 \\
\hline Distance_LN & 0.405 & 2.466 \\
\hline IncomeGAP_LN & 0.230 & 4.352 \\
\hline KOFGI_LN & 0.216 & 4.622 \\
\hline FTA & 0.433 & 2.309 \\
\hline Average & 0.296 & 3.821 \\
\hline
\end{tabular}

Source: Authors' own calculations

For comparison, for the 27 countries, the tolerance always remains above 0.2. See table 7 .

Table 7

Collinearity statistics for all the 27 countries

\begin{tabular}{|c|c|c|}
\hline Variable & Tolerance & VIF \\
\hline GDP_LN & 0.410 & 2.437 \\
\hline GDPPC_LN & 0.207 & 4.829 \\
\hline Distance_LN & 0.782 & 1.278 \\
\hline IncomeGAP_LN & 0.315 & 3.176 \\
\hline KOFGI_LN & 0.271 & 3.687 \\
\hline FTA & 0.853 & 1.172 \\
\hline Average & 0.473 & 2.763 \\
\hline
\end{tabular}

Source: Authors' own calculations 
According to Table 8 below, the predictions for overall trade, export, and import volumes for the FTAspecific countries are excellent.

The results are assessed based on the specific factors explored such as total trade flow, imports from China, or exports to China. Table 8 below presents the adjusted R-square values along with the correlation coefficients between the model and the dependent variable. The model displays excellent predictions.

Table 8

Adjusted R-squared values for FTA-specific countries

\begin{tabular}{|c|c|c|c|}
\hline Dependent Variable & $\mathbf{R}$ & Adjusted $\mathbf{R}^{2}$ & Explained Variance \\
\hline $\ln \left(\right.$ Trade $\left._{i j}\right)$ & $0.950^{* * *}$ & 0.898 & $89.8 \%$ \\
\hline $\ln \left(\right.$ Export $\left._{i j t}\right)$ & $0.933^{* * *}$ & 0.864 & $86.4 \%$ \\
\hline $\ln \left(\right.$ Import $\left._{i j t}\right)$ & $0.945^{* * *}$ & 0.888 & $88.8 \%$ \\
\hline$* * * \mathbf{p}<\mathbf{0 . 0 1}, * * \mathbf{p}<\mathbf{0 . 0 5}, \boldsymbol{*}^{*} \mathbf{p}<\mathbf{0 . 1}$ & \\
\hline
\end{tabular}

Source: Authors' own calculations

For comparison, for the 27 countries, the adjusted R-square is also high.

Table 9

Adjusted R-squared values for all the 27 countries

\begin{tabular}{|c|c|c|c|}
\hline Dependent Variable & $\mathbf{R}$ & Adjusted R 2 & Explained Variance \\
\hline $\ln \left(\right.$ Trade $\left._{i j}\right)$ & $0.948^{* * *}$ & 0.897 & $89.7 \%$ \\
\hline $\ln \left(\right.$ Export $\left._{i j t}\right)$ & $0.902^{* * *}$ & 0.811 & $81.1 \%$ \\
\hline $\ln \left(\right.$ Import $\left._{i j t}\right)$ & $0.919^{* * *}$ & 0.842 & $84.2 \%$ \\
\hline *** $\mathrm{p}<0.01, * * \mathrm{p}<0.05,{ }^{*} \mathrm{p}<0.1$ & \multicolumn{3}{|l}{} \\
\hline
\end{tabular}

Source: Authors' own calculations

\subsection{Overall Trade}

All the variables in Table 10 below are significant. It can be seen that, if distance increases, then overall trade decreases, and as the distance decreases, then trade increases. If KOFGI increases by as little as 5\%, then overall trade will increase by $54 \%$, and trade will increase by $245 \%$ if KOFGI increases by $15 \%$.

The same can be observed of the other significant positive coefficients of KOFGI and GDP. The effect of changes in the independent variables that are put in the natural logarithm is to alter the value of the dependent variable according to the following equation:

$$
\Delta y \%=\left(e^{\beta\left(\ln \left(\frac{[100+p]}{100}\right)\right)}-1\right) * 100 \%
$$

Table 10

Independent variables for FTA-specific countries: overall trade.

\begin{tabular}{|c|c|c|c|c|c|c|c|}
\hline \multirow[t]{2}{*}{ Variable } & \multirow[t]{2}{*}{ Coefficient } & \multicolumn{6}{|c|}{$\begin{array}{c}\begin{array}{c}\text { Effect of changes in the independent variable on the dependent } \\
\text { variable }\end{array} \\
\end{array}$} \\
\hline & & $-15 \%$ & $-10 \%$ & $-5 \%$ & $5 \%$ & $10 \%$ & $15 \%$ \\
\hline$G D P \_L N$ & $0.829 * * *$ & $-13 \%$ & $-8 \%$ & $-4 \%$ & $4 \%$ & $8 \%$ & $12 \%$ \\
\hline$G D P P C_{-} L N$ & $-0.541 * * *$ & $9 \%$ & $6 \%$ & $3 \%$ & $-3 \%$ & $-5 \%$ & $-7 \%$ \\
\hline Distance_LN & $-0.776^{* * *}$ & $13 \%$ & $9 \%$ & $4 \%$ & $-4 \%$ & $-7 \%$ & $-10 \%$ \\
\hline IncomeGAP_LN & $-0.251 * * *$ & $4 \%$ & $3 \%$ & $1 \%$ & $-1 \%$ & $-2 \%$ & $-3 \%$ \\
\hline KOFGI_LN & $8.854 * * *$ & $-76 \%$ & $-61 \%$ & $-37 \%$ & $54 \%$ & $133 \%$ & $245 \%$ \\
\hline
\end{tabular}

Source: Authors' own calculations 
Table above helps to analyze the impact of the independent variables on total trade flow between country $\mathrm{i}$ and China. It is shown that a 15\% reduction in distance returns a $13 \%$ increase in overall trade. Compared to the other variables, it seems that the effects of IncomeGAPijt and GDPPCijt are weak despite a $\mathrm{p}$ value of $<0.01$, and there would need to be a drastic change in order for these factors to show an impact on trade.

Concerning the binary variable, which takes the value 0 or 1 , the change for the dependent variable is calculated as:

$$
\Delta y=\left(e^{x}-1\right) * 100 \%
$$

According to this equation and the results of the regression analysis, FTA is significantly correlated with an increase in trade flow between country $i$ and China by $(e .538-1) * 100 \%=84 \%$ on average. The predictor for variables that include the natural logarithm can be seen in Table 11 below, where the upper and lower boundaries are based on 95\% confidence intervals.

With an FTA, overall trade increases by $84 \%$, and it can be said with $95 \%$ confidence that it will be in the range of $36 \%-149 \%$.

Table 11

FTA's 95\% confidence interval for FTA-specific countries: overall trade

\begin{tabular}{|c|c|c|c|c|c|c|}
\hline Variables & Coefficient & $\begin{array}{c}\text { Estimated } \\
\text { effect }\end{array}$ & $\begin{array}{l}\text { Lower } \\
\text { bound }\end{array}$ & $\begin{array}{l}\text { Estimated } \\
\text { effect (lower } \\
\text { bound) }\end{array}$ & $\begin{array}{l}\text { Upper } \\
\text { bound }\end{array}$ & $\begin{array}{l}\text { Estimated } \\
\text { effect (upper } \\
\text { bound) }\end{array}$ \\
\hline FTA & $0.610^{* * *}$ & $84 \%$ & 0.306 & $36 \%$ & 0.914 & $149 \%$ \\
\hline 0.01 & $* \mathrm{p}<0.1$ & & & & & \\
\hline
\end{tabular}

Source: Authors' own calculations

For comparison, for the 27 countries and overall trade, the independent variables have impact on total trade flow between country $i$ and China, apart from the income gap. 95\% confidence interval for the FTA coefficient is also significant, see in table 12 and 13.

Table 12

Independent variables for the 27 countries

\begin{tabular}{|c|c|c|c|c|c|c|c|}
\hline \multirow[t]{2}{*}{ Variable } & \multirow[t]{2}{*}{ Coefficient } & \multicolumn{6}{|c|}{$\begin{array}{l}\text { Effect of changes in the independent variable on the dependent } \\
\text { variable }\end{array}$} \\
\hline & & $-15 \%$ & $-10 \%$ & $-5 \%$ & $5 \%$ & $10 \%$ & $15 \%$ \\
\hline$G D P \_L N$ & $0.901 * * *$ & $-14 \%$ & $-9 \%$ & $-5 \%$ & $4 \%$ & $9 \%$ & $13 \%$ \\
\hline$G D P P C_{-} L N$ & $-0.351 * * *$ & $6 \%$ & $4 \%$ & $2 \%$ & $-2 \%$ & $-3 \%$ & $-5 \%$ \\
\hline Distance_LN & $-0.695^{* * *}$ & $12 \%$ & $8 \%$ & $4 \%$ & $-3 \%$ & $-6 \%$ & $-9 \%$ \\
\hline IncomeGAP_LN & 0.022 & $0 \%$ & $0 \%$ & $0 \%$ & $0 \%$ & $0 \%$ & $0 \%$ \\
\hline KOFGI_LN & $3.747 * * *$ & $-46 \%$ & $-33 \%$ & $-17 \%$ & $20 \%$ & $43 \%$ & $69 \%$ \\
\hline
\end{tabular}

Source: Authors' own calculations

Table 13

$95 \%$ confidence interval for the 27 countries

\begin{tabular}{|c|c|c|c|c|c|c|}
\hline Variables & Coefficient & $\begin{array}{c}\text { Estimated } \\
\text { effect }\end{array}$ & $\begin{array}{c}\text { Lower } \\
\text { bound }\end{array}$ & $\begin{array}{c}\text { Estimated } \\
\text { effect (lower } \\
\text { bound) }\end{array}$ & $\begin{array}{c}\text { Upper } \\
\text { bound }\end{array}$ & $\begin{array}{c}\text { Estimated } \\
\text { effect (upper } \\
\text { bound) }\end{array}$ \\
\hline$F T A$ & $0.538^{* * *}$ & $71 \%$ & 0.319 & $38 \%$ & 0.757 & $113 \%$ \\
\hline$* * * \mathrm{p}<\mathbf{0 . 0 1 , * *} \mathrm{p}<\mathbf{0 . 0 5 , * \mathrm { p } < \mathbf { 0 . 1 }}$ \\
\hline
\end{tabular}

Source: Authors' own calculations 


\subsection{Exports to China}

Table 14 demonstrates the findings for exports from FTA-specific countries to China. All variables are significant. When GDPPC increases, then exports decrease, and if GDPPC decreases, then exports increase. IF GDP increases, then exports increase as well, and if GDP decreases, then export volume also decreases. If KOFGI increases by only $5 \%$, then exports grow by $92 \%$, and export volume increases to $547 \%$ with a KOFGI increase of $15 \%$.

Table 14

Independent variables for FTA-specific countries: exports to China

\begin{tabular}{|c|c|c|c|c|c|c|c|}
\hline \multirow[t]{2}{*}{ Variable } & \multirow[t]{2}{*}{ Coefficient } & \multicolumn{6}{|c|}{$\begin{array}{c}\text { Effect of changes in the independent variable on the dependent } \\
\text { variable }\end{array}$} \\
\hline & & $-15 \%$ & $-10 \%$ & $-5 \%$ & $5 \%$ & $10 \%$ & $15 \%$ \\
\hline$G D P \_L N$ & $1.055^{* * *}$ & $-16 \%$ & $-11 \%$ & $-5 \%$ & $5 \%$ & $11 \%$ & $16 \%$ \\
\hline$G D P P C_{-} L N$ & $-0.840^{* * *}$ & $15 \%$ & $9 \%$ & $4 \%$ & $-4 \%$ & $-8 \%$ & $-11 \%$ \\
\hline Distance_LN & $-0.755^{* * *}$ & $13 \%$ & $8 \%$ & $4 \%$ & $-4 \%$ & $-7 \%$ & $-10 \%$ \\
\hline IncomeGAP_LN & $-0.348^{* * *}$ & $6 \%$ & $4 \%$ & $2 \%$ & $-2 \%$ & $-3 \%$ & $-5 \%$ \\
\hline KOFGI_LN & $13.364 * * *$ & $-89 \%$ & $-76 \%$ & $-50 \%$ & $92 \%$ & $257 \%$ & $547 \%$ \\
\hline
\end{tabular}

Source: Authors' own calculations

Export volume increases by $52 \%$ if the country has an FTA with China, and it can be said with $95 \%$ confidence that the volume will be in the range of $-2 \%-134 \%$. However, table 15 shows that the coefficient for FTA is not statistically significant with regards to $\mathrm{p}<0.05$, although it is significant with regards to $\mathrm{p}<0.1$. The trading partners of China did not experience a significant increase in export to China.

FTA's 95\% confidence interval for FTA-specific countries: exports to China

\begin{tabular}{|c|c|c|c|c|c|c|}
\hline 95\% confidence interval for the coefficient \\
\hline Variables & Coefficient & $\begin{array}{c}\text { Estimated } \\
\text { effect }\end{array}$ & $\begin{array}{c}\text { Lower } \\
\text { bound }\end{array}$ & $\begin{array}{c}\text { Estimated } \\
\text { effect (lower } \\
\text { bound) }\end{array}$ & $\begin{array}{c}\text { Upper } \\
\text { bound }\end{array}$ & $\begin{array}{c}\text { Estimated } \\
\text { effect (upper } \\
\text { bound) }\end{array}$ \\
\hline$F T A$ & $0.416^{*}$ & $52 \%$ & -0.017 & $-2 \%$ & 0.849 & $134 \%$ \\
\hline$* * * \mathrm{p}<\mathbf{0 . 0 1 , * *} \mathrm{p}<\mathbf{0 . 0 5 , * \mathrm { p } < \mathbf { 0 . 1 }}$ \\
\hline
\end{tabular}

Source: Authors' own calculations

For comparison, for the 27 countries and export to China, the independent variables have impact on trade flow between country $\mathrm{i}$ and China, apart from the income gap. Importantly, here, for the export volume, the FTA's coefficient is highly significant indicating that for all the 27 countries in the data set is examined, the export volume to China has increased but that was not the case for the 13 countries that had free trade agreement, see table 14 and 15 above. For the 27 countries, see in table 16 and 17 below.

Table 16

Independent variables for the 27 countries: export volume

\begin{tabular}{|c|c|c|c|c|c|c|c|}
\hline \multirow[t]{2}{*}{ Variable } & \multirow[t]{2}{*}{ Coefficient } & \multicolumn{6}{|c|}{$\begin{array}{l}\text { Effect of changes in the independent variable on the dependen } \\
\text { variable }\end{array}$} \\
\hline & & $-15 \%$ & $-10 \%$ & $-5 \%$ & $5 \%$ & $10 \%$ & $15 \%$ \\
\hline$G D P \_L N$ & $1.142^{* * *}$ & $-17 \%$ & $-11 \%$ & $-6 \%$ & $6 \%$ & $12 \%$ & $17 \%$ \\
\hline$G D P P C \_L N$ & $-0.755^{* * *}$ & $13 \%$ & $8 \%$ & $4 \%$ & $-4 \%$ & $-7 \%$ & $-10 \%$ \\
\hline Distance_LN & $-0.924 * * *$ & $16 \%$ & $10 \%$ & $5 \%$ & $-4 \%$ & $-8 \%$ & $-12 \%$ \\
\hline IncomeGAP_LN & 0.070 & $-1 \%$ & $-1 \%$ & $0 \%$ & $0 \%$ & $1 \%$ & $1 \%$ \\
\hline KOFGI_LN & $8.534 * * *$ & $-75 \%$ & $-59 \%$ & $-35 \%$ & $52 \%$ & $126 \%$ & $230 \%$ \\
\hline
\end{tabular}

Source: Authors' own calculations 
95\% confidence interval for the whole dataset: export volume.

\begin{tabular}{|c|c|c|c|c|c|c|}
\hline Variables & Coefficient & $\begin{array}{c}\text { Estimated } \\
\text { effect }\end{array}$ & $\begin{array}{c}\text { Lower } \\
\text { bound }\end{array}$ & $\begin{array}{c}\text { Estimated } \\
\text { effect (lower } \\
\text { bound) }\end{array}$ & $\begin{array}{c}\text { Upper } \\
\text { bound }\end{array}$ & $\begin{array}{c}\text { Estimated } \\
\text { effect (upper } \\
\text { bound) }\end{array}$ \\
\hline$F T A$ & $1.087 * * *$ & $197 \%$ & 0.654 & $92 \%$ & 1.520 & $357 \%$ \\
\hline$* * * \mathrm{p}<\mathbf{0 . 0 1 , * *} \mathrm{p}<\mathbf{0 . 0 5 , * \mathrm { p } < \mathbf { 0 . 1 }}$ \\
\hline
\end{tabular}

Source: Authors' own calculations

\subsection{Imports from China}

Table 18 shows the results for imports from China. IncomeGAP has a minimal effect regardless of whether it increases or decreases. If distance increases, then imports decrease, and if distance decreases, then import volume increases. If KOFGI increases by $15 \%$, then import volume increases by $159 \%$.

Table 18

Independent variables for FTA-specific countries: imports from China

\begin{tabular}{|c|c|c|c|c|c|c|c|}
\hline \multirow[t]{2}{*}{ Variable } & \multirow[t]{2}{*}{ Coefficient } & \multicolumn{6}{|c|}{$\begin{array}{c}\text { Effect of changes in the independent variable on the } \\
\text { dependent variable }\end{array}$} \\
\hline & & $-15 \%$ & $-10 \%$ & $-5 \%$ & $5 \%$ & $10 \%$ & $15 \%$ \\
\hline$G D P \_L N$ & $0.715^{* * *}$ & $-11 \%$ & $-7 \%$ & $-4 \%$ & $4 \%$ & $7 \%$ & $11 \%$ \\
\hline$G D P P C_{-} L N$ & $-0.433 * * *$ & $7 \%$ & $5 \%$ & $2 \%$ & $-2 \%$ & $-4 \%$ & $-6 \%$ \\
\hline Distance_LN & $-0.775^{* * *}$ & $13 \%$ & $9 \%$ & $4 \%$ & $-4 \%$ & $-7 \%$ & $-10 \%$ \\
\hline IncomeGAP_LN & $-0.176^{* * *}$ & $3 \%$ & $2 \%$ & $1 \%$ & $-1 \%$ & $-2 \%$ & $-2 \%$ \\
\hline KOFGI_LN & $6.822 * * *$ & $-67 \%$ & $-51 \%$ & $-30 \%$ & $39 \%$ & $92 \%$ & $159 \%$ \\
\hline
\end{tabular}

Source: Authors' own calculations

Table 19 below shows that import volume increases by 108\% if there is an FTA involved, and it can be said with $95 \%$ confidence that it will be in the range of $56 \%-178 \%$, i.e. countries that have entered into a FTA with China did indeed experience an increase in import from China.

Table 19

FTA's 95\% confidence interval for FTA-specific countries: imports from China

\begin{tabular}{|c|c|c|c|c|c|c|}
\hline Variables & Coefficient & $\begin{array}{c}\text { Estimated } \\
\text { effect }\end{array}$ & $\begin{array}{c}\text { Lower } \\
\text { bound }\end{array}$ & $\begin{array}{c}\text { Estimated } \\
\text { effect (lower } \\
\text { bound) }\end{array}$ & $\begin{array}{c}\text { Upper } \\
\text { bound }\end{array}$ & $\begin{array}{c}\text { Estimated } \\
\text { effect (upper } \\
\text { bound) }\end{array}$ \\
\hline$F T A$ & $0.734 * * *$ & $108 \%$ & 0.455 & $56 \%$ & 1.024 & $178 \%$ \\
\hline$* * * \mathrm{p}<0.01, * * \mathrm{p}<0.05, * \mathrm{p}<0.1$
\end{tabular}

Source: Authors' own calculations

For comparison, for the 27 countries and import to China, the independent variables have impact on trade flow between country $i$ and China, apart from the income gap. See in table 20 and 21. 
Guðjonsson, S., Minelgaite, I., Kristinsdóttir, H., Stankevičienè, J.
Who benefits of trade with China? Examining the effects of free trade agreements on trade flow...

Table 20

Independent variables for the 27 countries: import volume

\begin{tabular}{|c|c|c|c|c|c|c|c|}
\hline \multirow[t]{2}{*}{ Variable } & \multirow[t]{2}{*}{ Coefficient } & \multicolumn{6}{|c|}{$\begin{array}{l}\text { Effect of changes in the independent variable on the dependent } \\
\text { variable }\end{array}$} \\
\hline & & $-15 \%$ & $-10 \%$ & $-5 \%$ & $5 \%$ & $10 \%$ & $15 \%$ \\
\hline$G D P \_L N$ & $0.869^{* * *}$ & $-13 \%$ & $-9 \%$ & $-4 \%$ & $4 \%$ & $9 \%$ & $13 \%$ \\
\hline$G D P P C_{-} L N$ & $-0.314 * * *$ & $5 \%$ & $3 \%$ & $2 \%$ & $-2 \%$ & $-3 \%$ & $-4 \%$ \\
\hline Distance_LN & $-0.519 * * *$ & $9 \%$ & $6 \%$ & $3 \%$ & $-2 \%$ & $-5 \%$ & $-7 \%$ \\
\hline IncomeGAP_LN & $0.091 *$ & $-1 \%$ & $-1 \%$ & $0 \%$ & $0 \%$ & $1 \%$ & $1 \%$ \\
\hline KOFGI_LN & $2.653 * * *$ & $-35 \%$ & $-24 \%$ & $-13 \%$ & $14 \%$ & $29 \%$ & $45 \%$ \\
\hline
\end{tabular}

Source: Authors' own calculations

Table 21

95\% confidence interval for the whole dataset: import volume

\begin{tabular}{|c|c|c|c|c|c|c|}
\hline Variables & Coefficient & $\begin{array}{c}\text { Estimated } \\
\text { effect }\end{array}$ & $\begin{array}{c}\text { Lower } \\
\text { bound }\end{array}$ & $\begin{array}{c}\text { Estimated } \\
\text { effect (lower } \\
\text { bound) }\end{array}$ & $\begin{array}{c}\text { Upper } \\
\text { bound }\end{array}$ & $\begin{array}{c}\text { Estimated } \\
\text { effect (upper } \\
\text { bound) }\end{array}$ \\
\hline$F T A$ & $0.407 * *$ & $50 \%$ & 0.143 & $15 \%$ & 0.672 & $96 \%$ \\
\hline$* * * \mathrm{p}<\mathbf{0 . 0 1 , * *} \mathrm{p}<\mathbf{0 . 0 5 , *} \mathrm{p}<\mathbf{0 . 1}$
\end{tabular}

Source: Authors' own calculations

When the confidence interval for overall trade, export to China and Import from China is placed in a graph 1 here below, we can see that the overall trade has increased for all of the 27 countries as well as the 13 countries that have FTA with China. However, export to China has increased greatly for all of the 27 countries but less so for the 13 FTA countries and importantly, import from China has increased much more to the 13 FTA countries than to all of the 27 countries. Free trade agreements have been beneficial, particularly so for China.

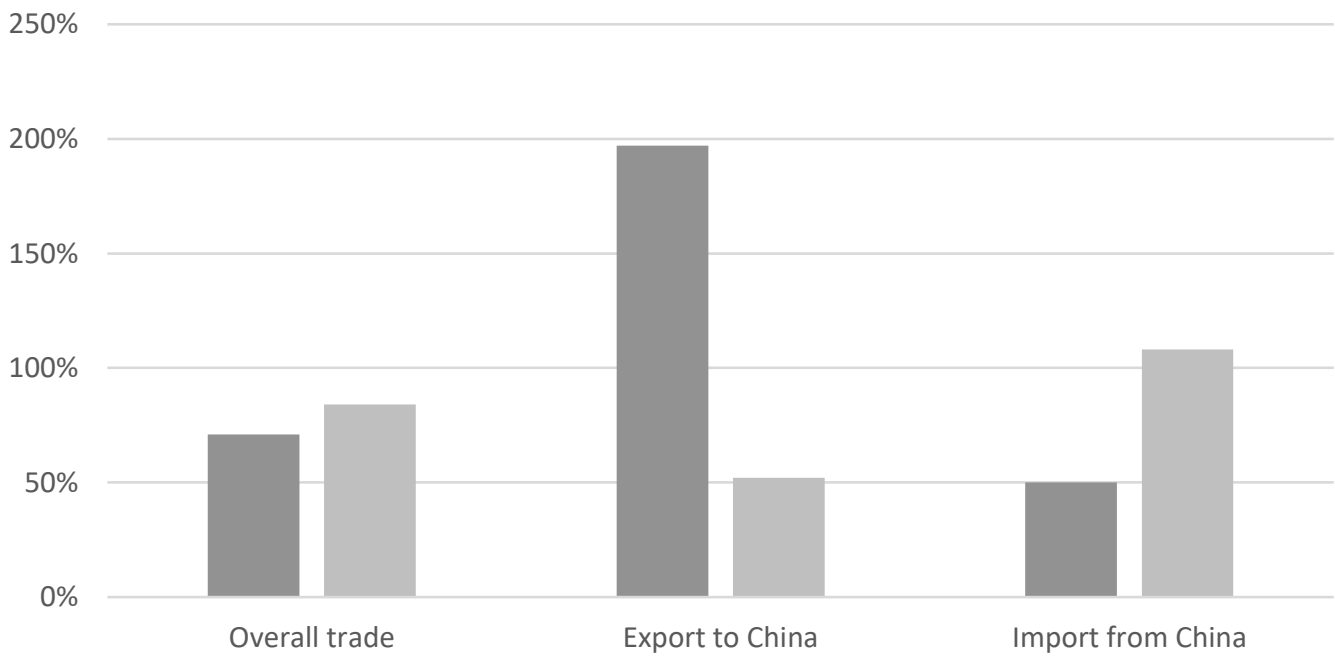

$\square 27$ Whole sampel $\square 13$ FTA countries

Picture 1. Confidence interval and estimated effect for overall trade, export to China and import from

China for all of the 27 countries as well as the 13 FTA countries 


\subsection{Discussion}

The aim of this research was to investigate who benefits from trade flow between China and other countries using the gravity model. Since it was found that FTA had un significant connection in export to China but statistically significant import from China from countries that have entered into an FTA with China, hints that China is the main beneficiary from the free trade, particularly with western countries. That should raise questions on the current trade war between the west, particularly USA and China. It would be particularly interesting to carry out further researches only focused on China and trade with the USA.

\section{CONCLUSIONS}

The FTA variable shows a positive connection to an increase in overall trade, export, and import. This connection is significant for import from China but not for export to China from other countries. However, for comparison if all the 27 countries in the data set are examined, both those that have free trade agreement with China and those who do not, there is significant connection for the export to China as well. This shows that China is surly the beneficiary for FTA with other countries. GDP shows a definite relationship to overall trade, export, and import. An increase in domestic production results in an increase in trade, so the size of an economy is connected to the quantity of trade with China, while GDPPC has a negative connection that is significant, indicating that China seems to conduct significantly less trade with countries that have a higher GDPPC. That could be due to collinearity because the countries that China is closest to and carries out the most trade with have lower GDPPC on average. Distance also has a significant negative connection with trade, indicating that China conducts significantly less trade with countries that are more geographically distant. This may be a result of transport costs or due to the culture of the countries that are closer to China being more similar to Chinese culture. This is a potential subject for further research.

Hypothesis One, concerning an increase in export volume for countries that have an FTA with China, is rejected as the results are only significant to the level of $p<0.1$. i. e. exports to China by FTA-specific countries, as entering into an FTA, is not shown to yield a significant increase in exports to China $(\mathrm{p}<0.1)$. Hypothesis Two regarding countries that have an FTA with China experiencing an increase in import from China is not rejected. This indicates that the existence of an FTA has a positive effect on exports from China to it's trading partners.

\section{REFERENCES}

Aitken, N.D. (1973). The effect of the EEC and EFTA on European trade: A temporal cross-section analysis. American Economic Review. 5, 881-892.

Anderson, J.E. (1979). A theoretical foundation for the fravity equation. The American Economic Review, 69(1), 106-116. Anderson, J., \& van Win, E. (2003). Gravity with gravitas: A solution to the border puzzle. The American Economic Review, 93(1), 170-192. doi: 10.1257/000282803321455214

Asia Regional Integration Center, (n.d.). Trade and Investment. Mongolia-People‘s Republic of China Free Trade Agreement. https://aric.adb.org/fta/peoples-republic-of-china-mongolia-free-trade-agreement

Baier, S.L., \& Bergstrand, J.H. (2007). Do free trade agreements actually increase members' international trade? Journal of International Economics. 71(1), 72-95. doi: 10.1016/j.jinteco.2006.02.005

Baier, S.L., \& Bergstrand, J.H. (2002). On the endogeneity international trade flows and free trade agreements. Unpublished manuscript, University of Notre Dame.

Bagwell, K., \& Staiger, Y. (2005). Erratum to multilateral trade negotiations, bilateral opportunism and the rules of GATT/WTO. Journal of International Economics. 67(2), 268-294. doi: 10.1016/j.jinteco.2005.06.001

Baldwin, R.E. (2006). Multilateralising regionalism: Spaghetti bowls as buildings blocs on the path to global free trade. The World Economy. 29(11), 1451-1518. 
Bayoumi, T. \& Eichengreen, B. (1997). Is regionalism simply a diversion? Evidence from the evolution of the EC and EFTA. In: Ito, Takatoshi, Krueger, Anne O. (Eds.), Regionalism vs. Multilateral Arrangements. The University of Chicago Press, Chicago.

Bergstrand, J.H. (1985). The gravity equation in international trade: Some microeconomics foundations and empirical evidence. The Review of Economics and Statistics. 67(3), 474-481. doi: 10.2307/1925976

Bergstrand, J.H. (1989). The generalized gravity equation, monopolistic competition, and the factor-proportions theory in international trade. The Review of Economics and Statistics. 71(1), 143-153. doi: 10.2307/1928061

Beugelsdijk, S., Ambos, B., \& Nell, P. C. (2018). Conceptualizing and measuring distance in international business research: Recurring questions and best practice guidelines. Journal of International Business Studies. doi.org/10.1057/s41267-018-0182-4.

Brugier, C.M. (2017). The EU's trade stratefy towards China: Lessons for an effective turn. Asia Europe Journal. 15, 199-212. doi: 10.1007/s10308-017-0475-4

Chang, V.K.L., \& Pieke, F.N. (2017). Europe‘s engagement with China: shifting Chinese views of the EU and the EUChina relationship. Asia Europe Journal. 16, 317-331. doi: 10.1007/s10308-017-0499-9

China FTA Network. (n.d.). Retrieved February 25, 2020 from http://fta.mofcom.gov.cn/english/index.shtml

Ciuriak, D., \& Kinjo, S. (2006). Trade specialization in the gravity model of international trade. Trade Policy Research 2005, 189-197.

Crowley, M., Exton, O., \& Han, L. (2018) Renegotiation of Trade Agreements and Firm Exporting Decisions: Evidence from the Impact of Brexit on UK Exports. Society of International Economic Law (SIEL), Sixth Biennial Global Conference, Available at SSRN: https://ssrn.com/abstract=3211689 or http://dx.doi.org/10.2139/ssrn.3211689

Deardorff, A. (1984). "Testing trade theories and predicting trade flows, "in R. Jones and P. Kenen, eds., Handbooks of international economics. 1, 467-517. Amsterdam: Elsevier. doi: 10.1016/S1573-4404(84)01013-3

Do, A. D., Nguyen Q. V., Le, Q. H., \& Ta, V. L. (2020). Green Supply Chain Management in Vietnam Industrial Zone: Province-Level Evidence. Journal of Asian Finance, Economics and Business, 7(7), 403-412. doi.org/10.13106/jafeb.2020.vol7.no7.403

Dreher, A., (2006). Does globalization affect growth? Evidence from a new index of globalization. Applied Economics. 38(10), 1091-1110. doi: 10.1080/00036840500392078

EFTA. (n.d.). European economic area (eea) / relations with the EU. https://www.efta.int/eea

EFTA. (n.d.). EEA agreement. https://www.efta.int/eea/eea-agreement

Eicher, T.S. \& Henn, C. (2011). In search of WTO trade effects: Preferential trade agreements promote trade strongly, but unevenly. Journal of International Economics. 83(2), 137-153. doi: 10.1016/j.jinteco.2010.12.002

Endoh, M. (2010). Trade creation and trade diversion in the EEC, the LAFTA and the CMEA: 1960-1994. Applied Economics, 31(2), 207-216. doi: 10.1080/000368499324435

Elliott, R. J.R., \&Ikemoto, K. (2004), “AFTA and the Asian Crisis: Help or Hindrance to ASEAN Intra- Regional Trade?” Asian Economic Journal, 18(1), 1-23.

ETH Zurich KOF. (2018, December 27). KOF globalisation index: Globalisation lull continues. https://kof.ethz.ch/en/news-and-events/media/press-releases/2018/12/kof-globalisation-indexglobalisation-lull-continues.html

European Union. (2019, August 6). What the EU does for its citizens. https://europa.eu/european-union/about-eu/whatthe-eu-does-for-its-citizens_en

European Union. (2019, March 13). Single market. https://europa.eu/european-union/topics/single-market_en

European Union. (2019, November 6). Trade. https://europa.eu/european-union/topics/trade_en

Frankel, J. \& Rose, A. (2002). An estimate of the effect of common currencies on trade and income. The Quarterly Journal of Economics. 117(2), 437-466. doi: 10.1162/003355302753650292

Frankel, J. A., Stein. E., \& Wei, S.J. (1995). Trading blocs and the Americas: The natural, the unnatural, and the supernatural. Journal of Development Economics. 47(1), 61-95.

Glesjer, H., Goossens, K., \& Vanden Eede, M. (1982). Inter-industry versus intra-industry specialization in exports and imports (1959-1970-1973). Journal of International Economics. 12(3-4), 363-369. doi: 10.1016/00221996(82)90046-0 
Gygli, S., Haelg, F., Potrafke, N., \& Sturm, J.E. (2019). The KOF globalisation index - revisited. The Review of International Organizations. 14, 543-574. doi: 10.1007/s11558-019-09344-2

Griese, O. (2006). EU-China relations-an assessment by the communications of the European Union. Asia Europe Journal. 4(4), 545-553. doi: 10.1007/s10308-006-0087-x

Handley, K. (2012). Country size, technology and manufacturing location. Review of International Economics, 20(1), 29-45. doi: 10.1111/j.1467-9396.2011.01005.x

Handley, K., \& Limao, N. (2017). "Policy uncertainty, trade and welfare: Theory and evidence for China and the United States“. American Economic Review. 107(9), 2731-83. doi: 10.1257/aer.20141419

He, L.Y., Lin, X., \& Liu, Q. (2020). How Did Free Trade Reshape the Transitional China? Evidence from Heterogeneous Exporters and Firm-Level Pollution Emissions. Emerging Markets Finance and Trade. 56(8), 1651 1676. doi.org/10.1080/1540496X.2019.1620101

International Monetary Fund. (2020). Direction of Trade Statistics (DOTS). https:// data.imf.org/?sk=9D6028D4-F14A464C-A2F2-59B2CD424B85

Irshad, M.S., Xin, Q., Hao, H., \& Arshad, H. (2017). SWOT analysis of Pakistan-China free trade agreement: Pros and cons. International Journal of Asian Social Science, 7(1), 45-53.

Irshad, M. S., Xin, Q., Hui, Z., \& Arshad, H. (2018). An empirical analysis of Pakistan's bilateral trade and trade potential with China: A gravity model approach, Cogent Economics \& Finance, 6(1). doi: 10.1080/23322039.2018.1504409

Kang, J.G., Yoon, J.M. (2020). Empirical Analysis on the Current Status and the Development of Bilateral Trade according to the Promotion of Korea-Japan FTA. Asia-pacific Journal of Convergent Research Interchange, 6(9). 4762. doi.org/10.47116/apjcri.2020.09.05

Kien, N.T., \& Hashimoto, Y. (2005). Economic analysis of ASE AN free trade area; By a country panel data. (Discussion Paper 05-12). Japan: Osaka University.

Kim, S., \& Shin, E.H. (2002). A longitudinal analysis of globalization and regionalization in international trade: A social network approach. Social Forces. 81(2), 445-468. doi: 10.1353/sof.2003.0014

Lai, P., \& Li, Q. (2013). Development in China‘s foreign trade: 2003-2012. China \& World Economy. 21(6), 58-78. https://doi.org/10.1111/j.1749-124X.2013.12046.x

Lakatos, C., \& Nilsson, L. (2017). The EU-Korea FTA: anticipation, trade policyuncertainty and impact. Rev World Econ 153, 179-198. DOI 10.1007/s10290-016-0261-1

Lanteigne, M. (2010). Northern exposure: Cross-regionalism and the China-Iceland preferential trade negotiations. The China Quarterly. 202, 362-280. doi: 10.1017/S0305741010000287

Linnemann, H. (1966). An econometric study of international trade flows. Amsterdam.

Linneman, H. (1996). On trade and growth. De Economist. 144(2), 325-332. Doi: 10.1007/BF01681906

Linsi, L., \& Mugge, D.K. (2019). Globalization and the growing defects of international economic statistics. Review of International Political Economy. 26(3), 361-383. doi.org/10.1080/09692290.2018.1560353

Markusen, J. R. (2004). Multinational Firms and the theory of international trade. The MIT Press. Cambridge: MA.

Medin, H. (2019). Free trade agreements in a small, open country: The case of Norway. The World Economy. 42(12), 3438-3446. doi.org/10.1111/twec.12876.

Melchior., A. (2018). Trade, USA and the Rise of China: Pains and Gains. Free Trade Agreements and Globalisation. 115130. DOI: $10.1007 / 978-3-319-92834-0 \_7$

McCallum, J. (1995). National borders matter: Canada-U.S. regional trade patterns. The American Economic Review. 85(3), 615-623.

Nguyen, D.B. (2019). A New Examination of the Impacts of Regional Trade Agreements on International Trade Patterns. Journal of Economic Integration 34 (2)2 pp. 236-279. Doi.org/10.11130/jei.2019.34.2.236

Park, D., \& Shin, K. (2009). Saving, inversment, and current account surplus in developing Asia. Asian Developent Bank Economics (working paper no. 158). doi: 10.2139/ssrn.1611454

Péridy, N. (2005). The trade effects of the Euro-Mediterranean partnership: What are the lessons for ASEAN countries? Journal of Asian Economics. 16(1), 125-139. doi: 10.1016/j.asieco.2004.12.001

Potrafke, N. (2014). The evidence on globalisation. The World Economy. 38(3), 509-552. doi: 10.1111/twec.12174 
Qiang, F., \& Bayanjargal, S. (2016). The study on trade policy and openness of Mongolia: Influences on trade flows between China-Mongolia-Russia (past and future). Chineses Business Review. 15(5), 249-264. doi: 10.17265/15371506/2016.05.004

Rose, A. (2004). Do we really know that the WTO increases trade? American Economic Review. 94(1), 98-114. doi: $10.1257 / 000282804322970724$

Schott, J.J. (1991). Trading blocs and the world trading system. The World Economy. 14(1), 1-18. doi: 10.1111/j.14679701.1991.tb00748.x

Shahriar,S., Qian, L., Kea, K. (2019). Determinants of exports in China's meat industry: a gravity model analysis Emerg. Mark. Finance Trade. 55 (2019), pp. 2544-2565. doi.org/10.1080/1540496X.2019.1578647

Shujiro, U., \& Misa, O. (2007). The impacts of free trade agreements on trade flows: An application of the gravity model approach. (Discussion Paper 07-E-052). Japan: Kyoto Gakuen University.

Soni S.K. (2018) China-Mongolia-Russia Economic Corridor: Opportunities and Challenges. In: Deepak B. (eds) China's Global Rebalancing and the New Silk Road. Springer, Singapore. doi: 10.1007/978-981-10-5972-8_9

Squartini, T., and Garlaschelli, D. (2014). Jan Tinbergen's legacy for economic networks: From the gravity model to quantum statistics. In: Abergel F., Aoyama H., Chakrabarti B., Chakraborti A., Ghosh A. (eds) Econophysics of Agent-Based Models. New Economic Windows. Springer, Cham. Doi: 10.1007/978-3-319-00023-7_9

Sumbramanian, A., \& Wei, S.J. (2007). The WTO promotes trade, strongly but unevenly. Journal of International Economics. 72(1), 151-175. doi: 10.1016/j.jinteco.2006.07.007

Tinbergen, J. (1962). Shaping the World Economy; Suggestions for an International Economic Policy. Books (Jan Tinbergen). Twentieth Century Fund, New York. Retrieved from http://hdl.handle.net/1765/16826

Ulzii-Ochir, N., \& Vorshilov, E. (2016). Study on the impact of a free trade agreement between Mongolia and the Eurasian Economic Union. The Northeast Asian Economic Review. 4(2), 37-51.

World Bank. (2019). Data. Retrieved March 6, 2020, from https://data.worldbank.org/

World Economic Forum. (2017, May 9). What is ASEAN? https://www.weforum.org/agenda/2017/05/what-isasean-explainer/

World Trade Organization. (2015). International trade statistics 2015. https://www.wto.org/english/res_e/ statis_e/its2015_e/its15_toc_e.htm

Xiang, H., Kuang, Y., \& Li, C. (2017). Impact of the China-Australia FTA on global coal production and trade. Journal of Policy Modeling, 39(1), 65-78. doi.org/10.1016/j.jpolmod.2017.01.001

Yihong, T., \& Weiwei, W. (2006). An analysis of trade potential between China and ASEAN within China-ASEAN FTA. Paper presented on 24-25 June at the Conference on WTO, China and the Asian Economies. Beijing, China.

Zhang, Y., Zhang, G., \& Fung, H.G. (2007). The prospects for China's free trade agreements. The Chinese Economy, 40(2), 5-35, doi: 10.2753/CES1097-1475400201

Zhao, W., Rut, J. (2020). Managing the "Post Miracle" Economy in China: Crisis of Growth Model and Policy Responses. Post-Communist Economies, 1-23 doi: bttps:/ / doi.org/ 10.1080/14631377.2020.1867427 